\title{
Esquisse d'une conception opératoire de l'objet technique
}

Jean Cazenobe

\section{(2) OpenEdition}

1 Journals

Édition électronique

URL : https://journals.openedition.org/tc/837

DOI : $10.4000 /$ tc. 837

ISSN : 1952-420X

Éditeur

Éditions de l'EHESS

\section{Édition imprimée}

Date de publication : 1 mars 1988

ISSN : 0248-6016

\section{Référence électronique}

Jean Cazenobe, "Esquisse d'une conception opératoire de l'objet technique », Techniques \& Culture [En ligne], 10 | 1988, mis en ligne le 23 janvier 2006, consulté le 29 septembre 2022. URL : http://

journals.openedition.org/tc/837 ; DOI : https://doi.org/10.4000/tc.837

Ce document a été généré automatiquement le 29 septembre 2022.

Tous droits réservés 


\section{Esquisse d'une conception opératoire de l'objet technique}

Jean Cazenobe 